\title{
The Effect of Jumping Task Based on Creative Problem Solving on Students' Problem Solving Ability
}

\section{Hobri}

Dr., corresponding author, Faculty of Teacher Training and Education, University of Jember, Indonesia, hobri.fkip@unej.ac.id

\section{Irma Khoirul Ummah}

Post-Graduate of Mathematics Education, Faculty of Teacher Training and Education, University of Jember, Indonesia, irma28leooo@gmail.com

\section{Nanik Yuliati}

Post-Graduate of Mathematics Education, Faculty of Teacher Training and Education, University of Jember, Indonesia, nanikyuliati@gmail.com

\section{Dafik}

Prof, Faculty of Teacher Training and Education, University of Jember, Indonesia, d.dafik@gmail.com

\begin{abstract}
This study aims to study the effectiveness of jumping task application based on creative problem solving in improving students' problem-solving abilities. The study was applied triangulation method, namely qualitative and quantitative methods. The research subject is eighth grade of Junior High School students. The research sample consists of three classes taken by applying cluster random sampling method. The qualitative research sample includes two students from experimental class, determined by purposive sampling based on their most unique answers. Data was obtained from pre-test and post-test on solving a problem sheet and also from an interview result. It implies the student problem solving tests of three classes are differences after the implementation of jumping task based on creative problem solving (CPS). The result of students' work and interview are analysed by qualitative method. It shows that the students' problem-solving abilities in mathematics learning with jumping task based on CPS is better than students' problem-solving abilities in mathematics learning with sharing task based on CPS, and students' problem-solving abilities in mathematics learning with sharing task based on CPS is better than students' problem-solving abilities in conventional model.
\end{abstract}

Keywords: jumping task, problem solving ability, problem solving, students, learning

Citation: Hobri, Ummah, I. K., Yuliati, N., \& Dafik (2020). The Effect of Jumping Task Based on Creative Problem Solving on Students' Problem Solving Ability. International Journal of Instruction, 13(1), 387-406. https://doi.org/10.29333/iji.2020.13126a 


\section{INTRODUCTION}

The learning process in the $21^{\text {st }}$ century aims to master the students critical thinking skill and it is able to solve problems, creative, innovative, as well as capable to communicate and collaborate (Hobri, 2016; Hobri \& Susanto, 2016; Sato, 2012). This is in line with Greiff (Scherer \& Gustafsson, 2015) who states that one of abilities in $21^{\text {st }}$ century need to be mastered by the students. These abilities refer to students' ability to solve complex problems based on real-life situation and require the interaction with an unknown environment. Therefore, it can be stated that the problem-solving ability is very important for the students.

According to Polya (in Hobri, 2009: 172), problem-solving is an attempt to find solutions and to achieve a goal which is not immediately accomplished. Problem-solving is regarded as "the most complex level of cognitive activities operative at the same time which is called forth all of individual intellectual parts including memory, perception, reasoning, conceptualization, language, emotion, motivation, self-confidence, and ability to control situation" (Caprioara, 2015). Based on these two statements, it can be concluded that problem-solving is the most complex level of individual cognitive activities that requires an effort to solve problems which involve all of the individual intellectual parts, namely memory, perception, reasoning, conceptualization, language, emotion, motivation, self-confidence, and ability to control situation.

Now, the problems faced by the students are more complex than they were, thus students' abilities are required to solve complex problems. In solving the complex problem, the students should relate the previous learned concepts to solve it. To increase the complex problem-solving skills, the role of teachers is very important. The teachers should be able to guide the students to achieve a high level of competence through the development of divergent and critical thinking skills (Sudiarta, 2005) and by giving students a higher order level task that requires the students to think divergently, critically, and creatively. Sato (2012) divides the task which needs high-order ability to finish it into two parts, namely sharing and jumping tasks.

Sharing task is a task that almost all students can comprehend and accomplish the problems. Meanwhile, jumping task is a task that has a higher level of difficulty than which not all students can accomplish the problems (Sato, 2012). Jumping task is challenging tasks, known to pose levels above the curricular demands (Saito et al., 2015; Hobri, 2016). This kind of task has long been applied in several countries, such as Japan (Sato, 2012), and are now being applied in several developing countries such as Indonesia (Saito et al., 2015). Jumping task is a task that contains problems that aim to improve students' abilities. The problem given in jumping task is the development and application of material concepts (Fatimah et al, 2018). This type of assignment is given so that students can think more critically and be challenged so that students will experience 'jumping' learning to encourage them to think harder and to get something from what is learned (Asari, 2017). Jumping task is the central part of the teaching that uses higher order thinking skills (HOTs) in Japan. Students with low performance have difficulties in solving jumping tasks. However, with collaborative learning, students can answer the percent jumping tasks. Some researchers showed that the applied of jumping 
task is better than sharing task in improve students' achievement (Anwar, 2017, Fatimah, et al, 2018, Putri, et al, 2019, Nofrion, 2019).

The purpose of giving jumping task is to challenge the student to think critically so that they do not get bored to study. The students need to use their ability to think critically, creatively and divergently in order to finish the jumping task because the jumping task questions are one of the high-order exercises. For solving the jumping task problems, a learning model is utilized to give the students opportunity practicing to solve the jumping task issues. Jumping task is one of the elements of Lesson Study for Learning Community. Several studies show that the integration of LSLC and model of learning has improved students' creativity (Saadah et al, 2019, Fauziah et al, 2019), critical thinking (Indrawanti et al, 2019), higher order thinking (Hobri et al, 2018), metacognitive (Hobri at al, 2018), collaborative ability (Hobri et al, 2018), and students' activity (Andini et al, 2017). To improve students' problem solving ability, it is needed to combine with learning model.

Now, the teacher is no longer a learning centre but the teacher is the facilitator. Teachers must be able to facilitate students so that learning can make students actively work and think. So that students are not bored and monotonous just by hearing an explanation from the teacher. One of them is the use of learning models that can attract students to be able to think and work actively and creatively. The learning model is known as Creative Problem Solving (CPS). CPS is a connection between problem-solving process and creative thinking skills. CPS is defined as a process to provide the framework or system to design or develop a new and useful result (Isaksen, 1993). CPS refers to the individual ability in solving problem using deep thinking beyond the normal thinking level, focusing on thinking to find various choices which are new and different from the usual before applying the problem-solving (Phaksunchai et al., 2014). Therefore, it can be concluded that CPS is a process that presents the framework to plan and develop more effective way to solve problems by using creative thinking ability.

CPS was first introduced by Sidney Parnes and Alex Osborn (Basadur, 1998; Isaksen, 1993; Kandemir, 2009; Puccio et al., 2006). Further, it was developed by Ishaksen and Treffinger (1985) who described the steps. The steps contain three components. They are 1) understanding a problem, 2) finding ideas, and 3) the plan to solve the problem. Moreover, the Osborn-Parnes CPS process (Kandemir, 2009) is classified into six forms, namely (1) finding object, (2) finding fact, (3) finding problem, (4) finding ideas, (5) finding solution, and (6) finding acceptance. CPS needs both convergent and divergent thinking (Kandemir, 2009). The main purpose of these steps is to find the best ideas from various ideas that have been found (Purwati, 2015).

Several studies show that students' mathematical problem solving ability with Creative Problem Solving (CPS) models better than students' mathematical problem solving skills with conventional learning (Purwati, 2015). CPS can improve students' creative thinking skills. 
The purpose of this study determines the effectiveness jumping task by using creative problem solving (CPS) on students' problem-solving abilities at eighth grade of junior high school of Nurul Islam (Nuris) Jember, East Java, Indonesia.

Table 1

Syntax Jumping Task Based on CPS

\begin{tabular}{|c|c|}
\hline Phase & Explanation \\
\hline $\begin{array}{l}\text { Phase } 1 \\
\text { Finding } \\
\text { Object }\end{array}$ & $\begin{array}{l}\text { Students discuss problem situations or illustrations submitted by the teacher and brainstorm a } \\
\text { number of goals or objectives that can be used for students' creative work. Throughout this } \\
\text { process students are expected to be able to make a consensus about the goals to be achieved by } \\
\text { the group. }\end{array}$ \\
\hline $\begin{array}{l}\text { Phase } 2 \\
\text { Finding Fact }\end{array}$ & $\begin{array}{l}\text { Students brainstorm all facts that might be related to that goal. The teacher lists each } \\
\text { perspective produced by students. The teacher gives time to students to reflect on any facts that } \\
\text { according to students are most relevant to the goals and solutions to the problem. }\end{array}$ \\
\hline $\begin{array}{l}\text { Phase } 3 \\
\text { Finding } \\
\text { Problem }\end{array}$ & $\begin{array}{l}\text { One of the most important aspects of creativity is redefining the issue, so that students can get } \\
\text { closer to the problem so that it is possible to find a clearer solution. One technique that can be } \\
\text { used is brainstorming a variety of possible ways to further clarify a problem. }\end{array}$ \\
\hline $\begin{array}{l}\text { Phase } 4 \\
\text { Finding Ideas }\end{array}$ & $\begin{array}{l}\text { In this step, the ideas of students enrolled in order to see possibilities become a solution to the } \\
\text { problem situation }\end{array}$ \\
\hline $\begin{array}{l}\text { Phase } 5 \\
\text { Finding } \\
\text { Solution }\end{array}$ & $\begin{array}{l}\text { At this stage, ideas that have the greatest potential are evaluated together. One way is to } \\
\text { normalize the criteria that can determine what the best solution should be. This criterion is } \\
\text { evaluated to produce a final assessment of appropriate ideas to be the solution to the problem } \\
\text { situation. }\end{array}$ \\
\hline $\begin{array}{l}\text { Phase } 6 \\
\text { Finding } \\
\text { Acceptance }\end{array}$ & $\begin{array}{l}\text { At this stage, students begin to consider real issues by thinking that has begun to change. } \\
\text { Students are expected to have new ways to solve many problems creatively. Student ideas are } \\
\text { expected to be used not only to solve problems, but also to achieve success. }\end{array}$ \\
\hline
\end{tabular}

Source Purwati, 2015

Indicator of problem solving according to Newman (at Clement, 1996) namely:

1) Reading

To find out the ability to read, students were asked to mention what was known and asked about the question.

2) Comprehension

At this stage students must be able to show the idea of a problem in the form of a general story problem that contains "What, Why, Where, When, Who, and How", ideas in mathematical problems are represented in the elements that are known, asked, and preconditions and also students must be able to state the question in its own sentence.

3) Transformation

At this stage, students try to find the relationship between what is known and asked, then to check the ability to transform the problem, students are asked to determine what methods, procedures, or strategies are used in solving the problem.

4) Process skill

At this stage, students are asked to implement a problem solving plan design through the stages of problem transformation to produce a desired solution.

5) Encoding

At this stage, students are asked to write the final answer to the problem given correctly based on the results they obtained at the process skill stage, and students must be able to write it according to the context of the problem. 


\section{METHOD}

\section{Research Design}

In this research, we applied a mixed method. Sugiyono (2017:404) states that mixed methods are a research method that combines the quantitative and qualitative methods used together in a research activity such that it will be a more comprehensive, valid, reliable and. Furthermore, to support the objectivity of the study, a triangulation model is obviously important.

The study was divided into two stages: (i) quantitative research methods, and (ii) qualitative research methods. In the first stage, quantitative research was carried out by using a quasi-experimental design (Post-test-Only Control design). In the second stage, qualitative research is carried out by interviewing two students based on the results of their answers in solving problem.

To determine the effect of giving jumping task based on CPS, a design was used quasiexperimental design (Post-test-Only Control Design). Prior to the research, homogeneity test was conducted to find out the three homogeneous classes. If all three classes are homogeneous, then the treatment is carried out on all three classes, one experimental class $\left(\mathrm{x}_{1}\right)$. was taught using jumping task based on CPS, one experimental class $\left(\mathrm{x}_{2}\right)$. was taught using sharing task based on CPS, and one control class was taught using conventional learning model $\left(\mathrm{x}_{3}\right)$. After being given treatment, then carried out post-test is in all three classes in the form of problem solving problems. The quasi-experimental design in this study is presented in Table 2.

Table 2

The quasi-experimental design (Post-test-Only Control Design)

\begin{tabular}{lll}
\hline \multicolumn{1}{c}{ Experimental class $\left(\mathrm{x}_{1}\right)$} & \multicolumn{1}{c}{ Experimental class $\left(\mathrm{x}_{2}\right)$} & \multicolumn{1}{c}{ Control class $\left(\mathrm{x}_{3}\right)$} \\
\hline Pre-test & Pre-test & Pre-test \\
\hline The learning model uses Creative & The learning model uses Creative & The learning model uses \\
Problem Solving (CPS). & Problem Solving (CPS). & conventional learning model. \\
\hline The task uses problem solving & The task uses problem solving & The task uses problem solving \\
with jumping task & with sharing task & with sharing task \\
\hline Post-test : & Post-test : & Post-test : \\
Problem Solving test & Problem Solving test & Problem Solving test. \\
\hline
\end{tabular}

To determine students' ability to solve problem solving problems, interviews were conducted with two students from $\mathrm{x}_{1}$ who had the most different answers. Figure 1 shows the triangulation model, where qualitative data is triangulated with quantitative data to determine the effectiveness of jumping tasks based on CPS on students' problem solving abilities. The research procedure is presented in Figure 1.

\section{Population}

The population of this study were eighth grade of Junior High School in Jember, Indonesia. The study applied cluster random sampling by selecting two classes randomly, resulting in one experimental class $\left(\mathrm{x}_{1}\right)$ of 34 students taught by using jumping tasks based on CPS. Another class were the experimental class $\left(\mathrm{x}_{2}\right)$ of 34 students taught by using sharing tasks based on CPS, and the rest were the control class 
$\left(\mathrm{x}_{3}\right)$ of 34 students taught using conventional model. To support the objectivity of quantitative data, interviews were conducted by selecting two students from the experimental class $\left(\mathrm{x}_{1}\right)$ with purposive sampling technique which respected to the most different answers.

\section{Instruments}

The instruments developed in this are test, observation, and interviews. The problemsolving tests are consisted of pre-test and post-test. The results of both tests are used to find out the effectiveness of jumping task based on CPS on students' problem-solving abilities. Apart from those, it is also completed with lesson study for learning community (LSLC) and student worksheets. The CPS of the LSLC utilized in experimental class $\left(\mathrm{x}_{1}\right)$ is the same as the CPS used in experimental class $\left(\mathrm{x}_{2}\right)$. In experimental class $\left(\mathrm{x}_{1}\right)$, the students' worksheets consisted of jumping task exercises, while those in experimental class $\left(\mathrm{x}_{2}\right)$ consisted of sharing task exercises. In control class $\left(\mathrm{x}_{3}\right)$, the instruction applies a conventional method where teachers as the centre of learning and practice. The questions are given in the form of simple problem exercises and problem-solving exercises.

The instrument used in this study has been validated by three mathematics education lecturers at the University of Jember, Indonesia and it has been declared valid. Validity test is done in the form of the validity of the format, content, and language. The research instrument is also equipped by an observation sheet to see the learning activities associates with teacher plan or not.

\section{Task}

In this research students are asked to deal with the following jumping, and sharing task, as presented in Table 3. 


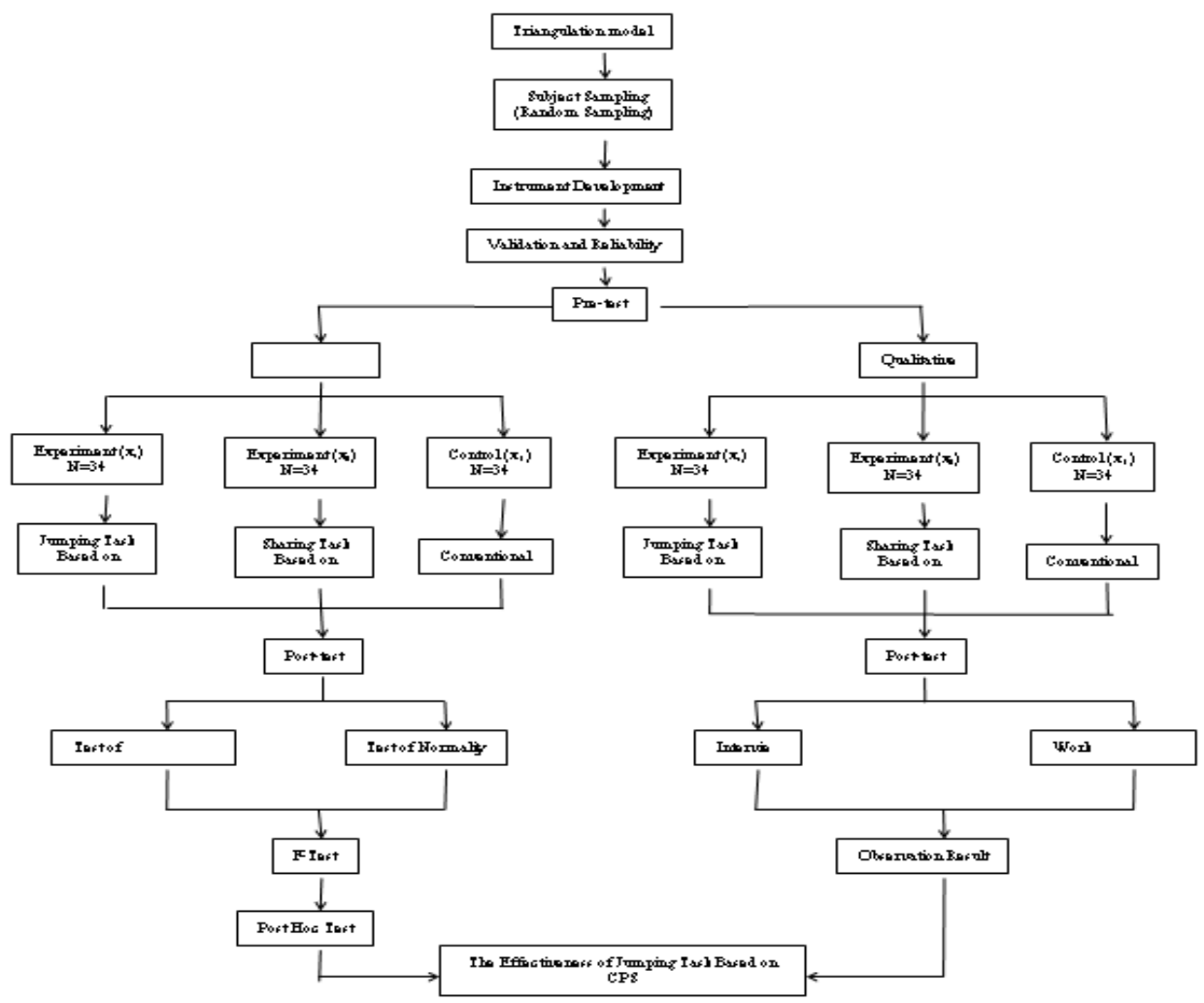

Figure 1

Triangulation Model

Table 3

The type and Bloom's taxonomy of sharing and jumping task problem

\begin{tabular}{|c|c|c|}
\hline $\begin{array}{l}\text { Type of } \\
\text { Problem }\end{array}$ & Task (Bloom’s Taxonomy) & Explanation \\
\hline $\begin{array}{l}\text { Sharing } \\
\text { Task }\end{array}$ & $\begin{array}{l}\text { Andi goes to school riding a bicycle. After being } \\
\text { measured with a tool connected to Andi's bike } \\
\text { called a tachometer, it is known that the number } \\
\text { of bicycle wheels rotates } 200 \text { times to get to } \\
\text { school. If Andi's wheel fingers are } 21 \mathrm{~cm} \text {, how } \\
\text { far is Andi's house going to school? (C4) }\end{array}$ & $\begin{array}{l}\text { Students can not directly use the information that } \\
\text { is known to solve the problem; it takes different } \\
\text { information to solve it. In this problem, students } \\
\text { must first determine the circumference of the } \\
\text { wheel (around the circle) and use it to determine } \\
\text { the distance of Andi's house to school. }\end{array}$ \\
\hline $\begin{array}{l}\text { Jumping } \\
\text { Task }\end{array}$ & $\begin{array}{l}\text { Bell } X_{1} \text { is the first supersonic aircraft developed } \\
\text { by the United States in } 1940 \text { with a speed of } \\
1255 \mathrm{~km} / \text { hour. If at any time the Bell } X_{1} \\
\text { circulates around the moon in a full rotation for } \\
10 \text { hours with a circular path. What is the height } \\
\text { of the Bell } X_{1} \text { plane's path from the moon's } \\
\text { surface? (note the fingers of the moon) (C5) }\end{array}$ & $\begin{array}{l}\text { There is information that is not written on the } \\
\text { problem, students must be able to find the missing } \\
\text { information and use it to solve the problem. } \\
\text { Students must be able to determine how many } \\
\text { fingers of the moon, then search the } \\
\text { circumference of the path using the speed } \\
\text { formula, then use it to find the radius of the path, } \\
\text { and then determine the difference between the } \\
\text { radius of the moon and the radius of the track. }\end{array}$ \\
\hline
\end{tabular}




\section{Data Collection and Data Analysis}

This study applied pre-test and post-test to collect the data. The pre-test was used to find out the students' initial problem-solving abilities. Furthermore, the homogeneity test on the results pre-test scores served as the basis of sample selection resulted in three homogeneous classes with cluster random sampling. Meanwhile, post-test was done after the three classes, $\mathrm{x}_{1}, \mathrm{x}_{2}$, and $\mathrm{x}_{3}$ were given treatment. Quantitative data were analyzed by inferential statistics using SPSS software. While the qualitative data is obtained by in-depth interviews with two students from the experimental class $\left(\mathrm{x}_{1}\right)$.

Descriptive statistic and inferential statistics are used to analyse quantitative data. The descriptive statistic contains some information such as mean and standard deviation. While to test the hypothesis, we use an inferential statistic, namely variant test (F-test) with a significance level of 0.05 . Prior to F-test analysis, we first tested the normality and homogeneity. If the results of the F-test show a significant difference, then a further test (Post Hoc Test) will be done by Bonferroni Test. It is conducted to determine the differences of student problem solving ability.

At the final stage we choose two students who had the most different answers on their post-test result from the experimental class $\left(\mathrm{x}_{1}\right)$. We did in-depth interviews to them to explore their ability in solving the problems.

\section{FINDINGS}

Before presenting and discussing the results, we will discuss about the problem solving test, its validity, and reliability. The problem solving test is presented in Table 4.

Table 4

The problem solving test

An architect plans to make a garden as in Figure. If around the
park a tree will be planted with a distance between two trees 2
m. How many trees does the architect need? Note : the distance
of ..... is $5 \mathrm{~m}$ (C3)
$\begin{aligned} & \text { Mr. Andi plans to make a square garden with a side length of } 15 \\ & \text { m. In the middle of the park was built a fish pond like figure } \\ & \text { (white). Outside the pond will be planted with grass. If the price } \\ & \text { of perennial planting per m }{ }^{2} \text { is IDR } 50,000 \text {, what is the cost } \\ & \text { needed by Mr. Andi to plant the grass? Note : the distance of } \\ & \text {..... is } 7 \text { m (C3) } \\ & \text { Mr. Banu has a wide circular steel plate154 } \mathrm{m}^{2} \text {. This plate is used to close the tubular water } \\ & \text { reservoir. The perimeter of the plate is nailed in such a way that the distance between } 2 \text { nails is } 0.5 \\ & \text { m. How many nails does Mr. Banu need to surround the steel plate? (C4) }\end{aligned}$
3.

We need to test a validity and reliability of our post-test instrument. The following tables show the validity and reliability results. 
Table 5

The validity of problem solving test

\begin{tabular}{|c|c|c|c|c|c|}
\hline \multicolumn{6}{|c|}{ Correlations $^{\mathrm{a}}$} \\
\hline & & No.1 & No. 2 & No.3 & Sum \\
\hline \multirow[t]{2}{*}{ No.1 } & Pearson Correlation & 1 & $.403^{*}$ & $.658^{* *}$ & $.865^{* *}$ \\
\hline & Sig. (2-tailed) & & .018 & .000 & .000 \\
\hline \multirow[t]{2}{*}{ No.2 } & Pearson Correlation & $.403^{*}$ & 1 & $.358^{*}$ & $.712^{* *}$ \\
\hline & Sig. (2-tailed) & .018 & & .037 & .000 \\
\hline \multirow[t]{2}{*}{ No.3 } & Pearson Correlation & $.658^{* * *}$ & $.358^{*}$ & 1 & $.825^{* *}$ \\
\hline & Sig. (2-tailed) & .000 & .037 & & .000 \\
\hline \multirow[t]{3}{*}{ Sum } & Pearson Correlation & $.865^{* *}$ & $.712^{* *}$ & $.825^{* *}$ & 1 \\
\hline & Sig. (2-tailed) & .000 & .000 & .000 & \\
\hline & $\mathrm{N}$ & 34 & 34 & 34 & 34 \\
\hline
\end{tabular}

*. Correlation is significant at the 0.05 level (2-tailed).

**. Correlation is significant at the 0.01 level (2-tailed).

Table 6

The reliability of problem solving test

Reliability Statistics

\begin{tabular}{ll}
\hline Cronbach's Alpha & N of Items \\
\hline .731 & 3 \\
\hline
\end{tabular}

Based on Table 5, it can be seen that the value of $r_{\text {count }}$ of number 1 is 0.865 , of number 2 is 0.712 , and of number 3 is 0.825 . All of items produce a value of $r_{\text {count }}>r_{\text {table }}$ with $\mathrm{N}$ $=34$, and sig. (2-tailed) is $0.000<0.05$, thus all items are valid.

Based on Table 6, it can be seen that the overall reliability value is 0.731 and $r_{\text {tabel }}$ of significance level $5 \%$ with $\mathrm{df}=\mathrm{N}-1=33, \mathrm{r}_{\text {table }}=0.666$. Therefore $\mathrm{r}_{\text {count }}>\mathrm{r}_{\text {table. }}$ It concludes that the instrument items are reliable.

Percentage of problem solving ability
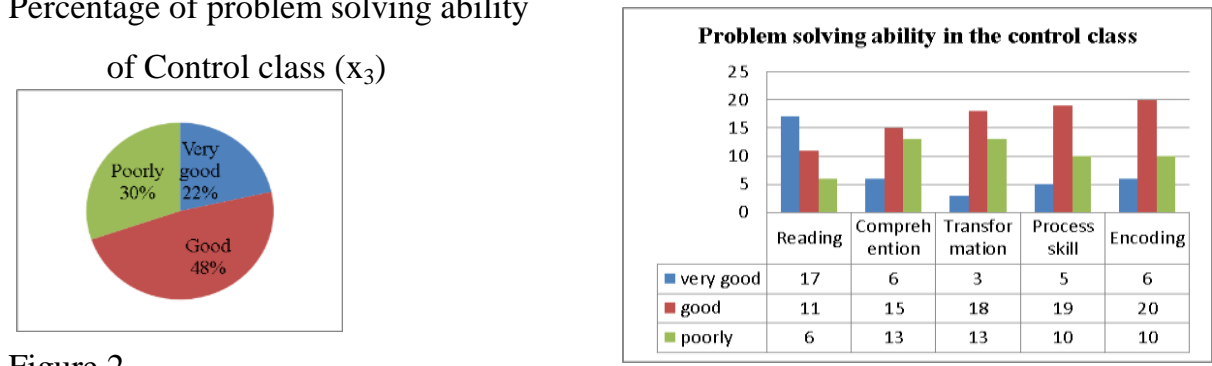

Figure 2

The distribution of student problem solving ability in the control class $\left(\mathrm{x}_{3}\right)$ 
Percentage of problem solving ability of experimental class $\left(\mathrm{x}_{2}\right)$
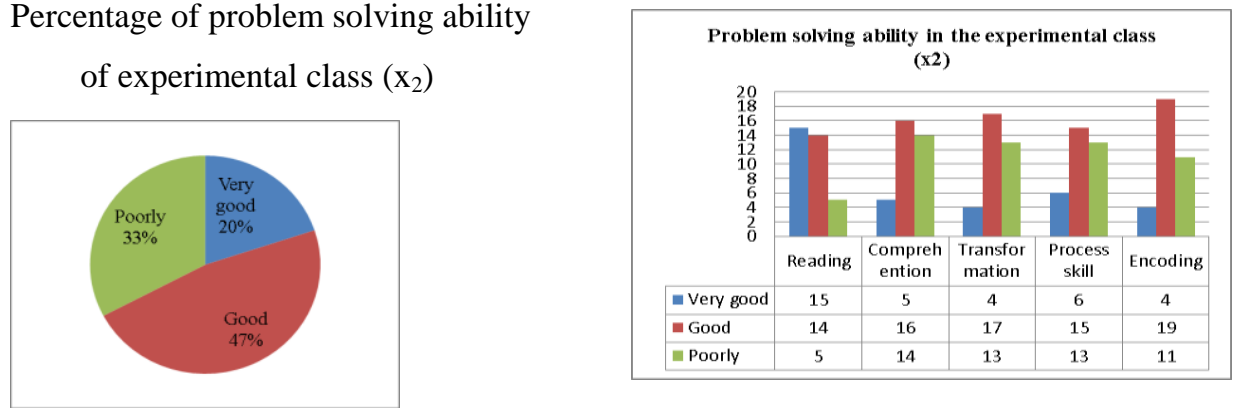

Figure 3

The distribution of student problem solving ability in the experimental class $\left(\mathrm{x}_{2}\right)$

Percentage of problem solving ability of experimental class $\left(\mathrm{x}_{1}\right)$
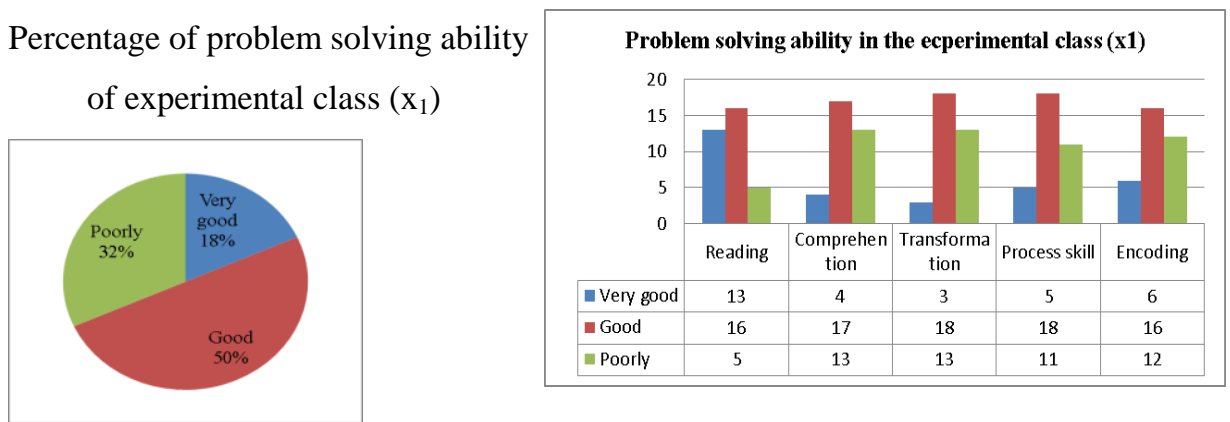

Figure 4

The distribution of student problem solving ability in the experimental class $\left(\mathrm{x}_{1}\right)$

To determine the effect of using jumping tasks based on CPS, F-test was conducted on the average score of pre-test and post-test in experiment class $\left(\mathrm{x}_{1}\right)$, experiment class $\left(\mathrm{x}_{2}\right)$, and control class $\left(\mathrm{x}_{3}\right)$. Table 6 shows the results of the homogeneity test to find out whether the three classes are homogeneous or not?

Table 7

The homogeneity test result of problem solving ability between the experimental class $\left(\mathrm{x}_{1}\right)$, experimental class $\left(\mathrm{x}_{2}\right)$, and control class $\left(\mathrm{x}_{3}\right)$

\begin{tabular}{llll}
\hline Value & \multicolumn{3}{l}{ Test of Homogeneity of Variances } \\
\hline Levene Statistic & df1 & df2 & Sig. \\
\hline .622 & 2 & 99 & .539
\end{tabular}

The result of homogeneity test using Levene statistic method is marked by significant scores $(0.539)$. It is higher than the significant level (0.05). It concludes that the initial ability of the experimental class $\left(\mathrm{x}_{1}\right)$, experimental class $\left(\mathrm{x}_{2}\right)$, and control class $\left(\mathrm{x}_{3}\right)$ are homogenous. Since the three classes are homogenous, the research can be conducted to determine the effect of using jumping task based on CPS on students' problem solving abilities (Basadur, 1982; Marhamah et al., 2017). 
Table 8

The mean scores of pre-test results between the experimental class $\left(\mathrm{x}_{1}\right)$, experimental class $\left(\mathrm{x}_{2}\right)$, and control class $\left(\mathrm{x}_{3}\right)$

\begin{tabular}{lccc}
\hline \multicolumn{1}{c}{ Group } & $\mathrm{N}$ & Mean & SD \\
\hline Experimental Class $\left(\mathrm{x}_{1}\right)$ & 34 & 49.85 & 15.32 \\
Experimental Class $\left(\mathrm{x}_{2}\right)$ & 34 & 50.17 & 13.69 \\
Control Class $\left(\mathrm{x}_{3}\right)$ & 34 & 49.67 & 13.36 \\
\hline
\end{tabular}

The distribution of pre-test results reaches 0.05 and post skewness test is marked at 0.00 . The mean score of the experimental class $\left(\mathrm{x}_{1}\right)$ reaches $49.85(\mathrm{SD}=15.32)$, while the experimental class $\left(\mathrm{x}_{2}\right)$ is marked by a mean score $50.17(\mathrm{SD}=13.69)$, and the control class $\left(\mathrm{x}_{3}\right)$ is marked by a mean score $49.67(\mathrm{SD}=13.36)$. The difference in the pre-test scores between the three groups is $[\mathrm{t}(102)=0.602, \mathrm{p}>0.05]$, which is found insignificant.

Table 9

The mean score post-test results between the experimental class $\left(\mathrm{x}_{1}\right)$, experimental class $\left(\mathrm{x}_{2}\right)$, and control class $\left(\mathrm{x}_{3}\right)$

\begin{tabular}{llll}
\hline Group & $\mathrm{N}$ & Mean & SD \\
\hline Experimental Class $\left(\mathrm{x}_{1}\right)$ & 34 & 78.35 & 11.96 \\
Experimental Class $\left(\mathrm{x}_{2}\right)$ & 34 & 67.12 & $13: 34$ \\
Control Class $\left(\mathrm{x}_{3}\right)$ & 34 & 58.76 & 11.84 \\
\hline
\end{tabular}

Table presents the post-test results of experimental class $\left(\mathrm{x}_{1}\right)$, marked at 78.35 (SD = 11.96), while the experimental class $\left(\mathrm{x}_{2}\right)$ gained $67.12(\mathrm{SD}=13.34)$, and another in control class $\left(\mathrm{x}_{3}\right)$ reached $58.76(\mathrm{SD}=11.84)$. Table 9 shows there is significant difference between the three classes as indicated by $(\mathrm{t}(102)=-6.401, \mathrm{p}<0.05)$.

Table 10

The result of normality test of problem-solving ability

Tests of Normality

\begin{tabular}{lllllll}
\hline \multicolumn{3}{l}{ Kolmogorov-Smirnov $^{\mathrm{a}}$} & \multicolumn{5}{l}{ Shapiro-Wilk } \\
\hline & Statistic & $\mathrm{df}$ & Sig. & Statistic & df & Sig. \\
\hline Value & .060 & 102 & .200 & .977 & 102 & .067 \\
\hline
\end{tabular}

The results of Kolmogorov-Smirnov normality test that had been done, the test indicated Sig. score at 0.200 more than 0.05 . Thus, it could be concluded that the data is normally distributed (Purwati, 2015).

Table 11

The results of homogeneity post-test of problem-solving ability

\begin{tabular}{llll}
\hline Value & \multicolumn{3}{l}{ Test of Homogeneity of Variances } \\
\hline Levene Statistic & df1 & df2 & Sig. \\
\hline .442 & 2 & 99 & .644 \\
\hline
\end{tabular}

Based on Table 11, the results of homogeneity test using Levene statistic method obtained the significance score at 0.644. It is more than the significant level of 0.05 . 
This finding concluded that the abilities of three classes were homogenous (Basadur, 1982; Marhamah et al., 2017). Since three classes were normal and homogenous, then the F-test can be performed.

Table 12

The result of variant test (F-test) of problem-solving ability

\begin{tabular}{llllll}
\hline Value & \multicolumn{5}{c}{ ANOVA } \\
\hline & Sum of Squares & df & Mean Square & F & Sig. \\
\hline Between Groups & 6569.961 & 3284.980 & 2 & 21368 & .000 \\
Within Groups & 15219.412 & 99 & 153731 & & \\
Total & 21789.373 & 101 & & & \\
\hline
\end{tabular}

Table 11 shows the variant test result of problem-solving abilities gained sig.0.000, which is less than the significant level of 0.05 . The result revealed that the variant differences of problem-solving ability among experimental class $\left(\mathrm{x}_{1}\right)$, experimental class $\left(\mathrm{x}_{2}\right)$, and control class $\left(\mathrm{x}_{3}\right)$ are significant. Since there are significant variance differences, it must be tested further (Post Hoc Test) with Bonferroni test to determine the difference between one treatment and another treatment (Basadur, 1982).

Table 13

The results of Post Hoc Test problem solving ability

\begin{tabular}{|c|c|c|c|c|c|c|}
\hline \multicolumn{2}{|c|}{ Value Bonferroni } & \multicolumn{5}{|c|}{ Multiple Comparisons } \\
\hline \multirow[b]{2}{*}{ (I) Class } & \multirow[b]{2}{*}{ (J) Class } & \multirow{2}{*}{$\begin{array}{l}\text { Mean Difference } \\
(\mathrm{I}-\mathrm{J})\end{array}$} & \multirow[b]{2}{*}{ Std. Error } & \multirow[b]{2}{*}{ Sig. } & \multicolumn{2}{|c|}{ 95\% Confidence Interval } \\
\hline & & & & & Lower Bound & Upper Bound \\
\hline \multirow{2}{*}{$\begin{array}{l}\text { Experimenta } \\
1 \text { Class }\left(x_{1}\right)\end{array}$} & Experimental Class $\left(\mathrm{x}_{2}\right)$ & $11.23529^{*}$ & 3.00716 & .001 & 3.9118 & 18.5588 \\
\hline & Control Class $\left(\mathrm{x}_{3}\right)$ & $19.58824^{*}$ & 3.00716 & .000 & 12.2648 & 26.9117 \\
\hline \multirow{2}{*}{$\begin{array}{l}\text { Experimenta } \\
1 \text { Class }\left(x_{2}\right)\end{array}$} & Experimental Class $\left(\mathrm{x}_{1}\right)$ & $-11.23529^{*}$ & 3.00716 & .001 & -18.5588 & -3.9118 \\
\hline & Control Class $\left(\mathrm{x}_{3}\right)$ & $8.35294^{*}$ & 3.00716 & .020 & 1.0295 & 15.6764 \\
\hline \multirow{2}{*}{$\begin{array}{l}\text { Control } \\
\text { Class }\left(\mathrm{x}_{3}\right)\end{array}$} & Experimental Class $\left(\mathrm{x}_{1}\right)$ & $-19.58824^{*}$ & 3.00716 & .000 & -26.9117 & -12.2648 \\
\hline & Experimental Class $\left(\mathrm{x}_{2}\right)$ & $-8.35294^{*}$ & 3.00716 & .020 & -15.6764 & -1.0295 \\
\hline
\end{tabular}

Based on Table 13, it is found that problem-solving abilities in all 3 classes are significantly different (indicated by $*$ ). Experimental class $\left(\mathrm{x}_{1}\right)$ has a mean difference of 11.235 with experimental class $\left(\mathrm{x}_{2}\right)$ and 19.588 with control class $\left(\mathrm{x}_{3}\right)$. Experimental class $\left(\mathrm{x}_{2}\right)$ has an average difference of -11.235 with experimental class $\left(\mathrm{x}_{1}\right)$ and 8.353 with control class $\left(\mathrm{x}_{3}\right)$.

From these results, it can be concluded that the experimental class $\left(\mathrm{x}_{1}\right)$ has more significant influence than experiment class $\left(\mathrm{x}_{2}\right)$ and the control class $\left(\mathrm{x}_{3}\right)$ and experiment class $\left(\mathrm{x}_{2}\right)$ have more significant influence than the control class $\left(\mathrm{x}_{3}\right)$. The results of this conclusion can be written with problem solving abilities in experiment class $\left(\mathrm{x}_{1}\right)>$ experiment class $\left(\mathrm{x}_{2}\right)>$ control class $\left(\mathrm{x}_{3}\right)$. 
To convince our result, we distributed observation to all subjects of experimental class $\left(\mathrm{x}_{1}\right)$, items done by 12 observers and it used Likert scale encompassing very active (score 5), active (score 4), hesitate (score 3), inactive (score 2), very inactive (score 1). The observation result can be shown in the following chart.
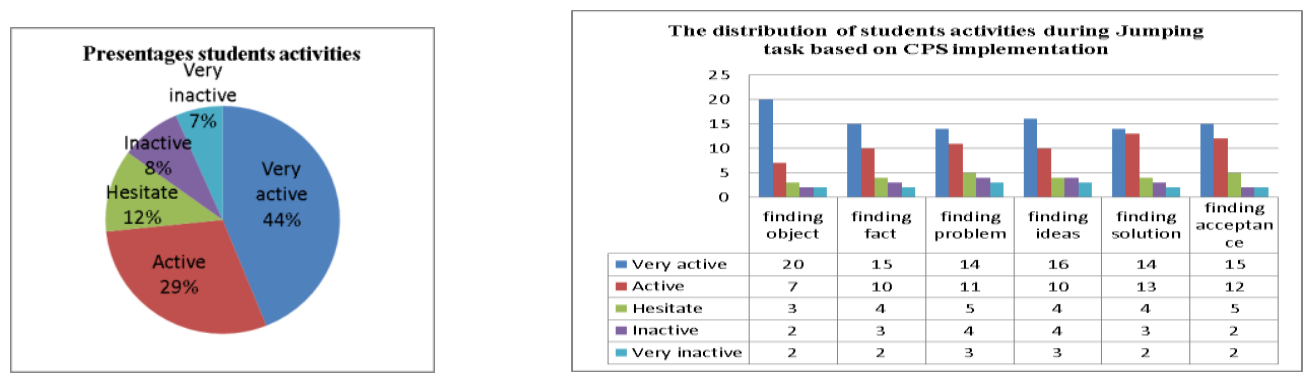

Figure 5

The observation result distribution of all subjects in experimental class $\left(\mathrm{x}_{1}\right)$

Based on Figure 5, the student involved in the observation are 34 students. It is found that the highest score of observation criteria reaches $44 \%$ of research subjects which indicates that, during jumping task based on CPS implementation. Students are strongly active to engage with the problem solving and $29 \%$ of students reach the active level, and the rest of $12 \%$ are in hesitate, inactive, and very inactive. It can be conclude that jumping task based on CPS can work well in the learning process on solving problem.

Percentage of problem solving ability

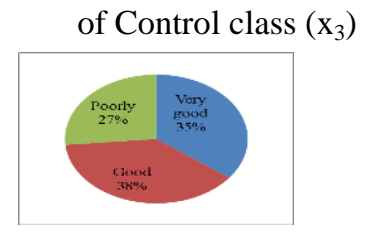

Figure 6

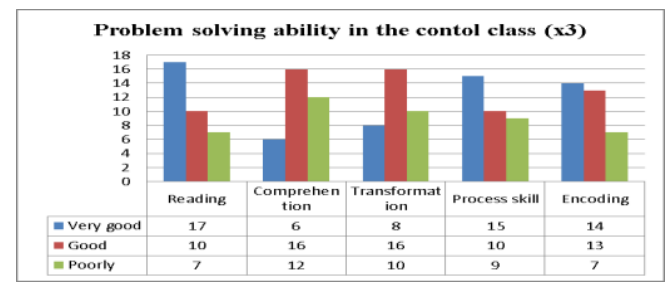

The distribution of student problem solving ability in the control class $\left(\mathrm{x}_{3}\right)$

Percentage of problem solving ability of Experimental class $\left(\mathrm{x}_{2}\right)$
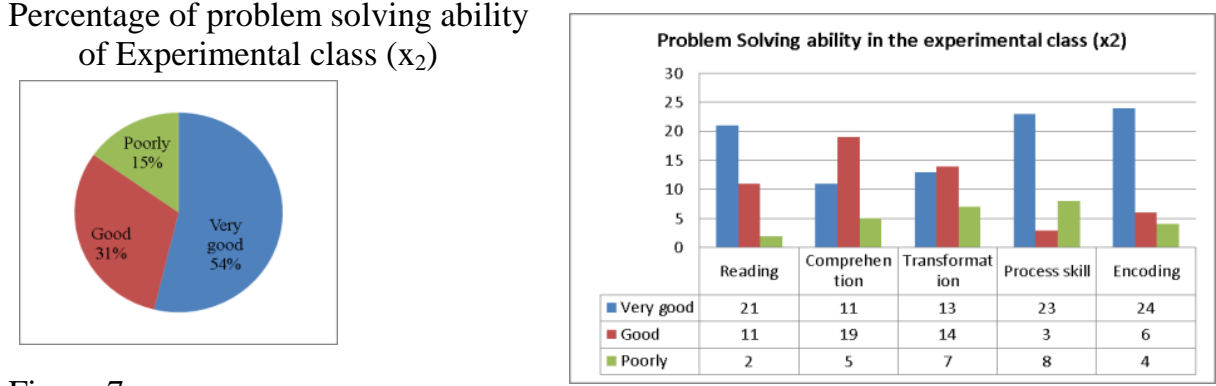

Figure 7

The distribution of student problem solving ability in the experimental class $\left(\mathrm{x}_{2}\right)$ 
Percentage of problem solving ability
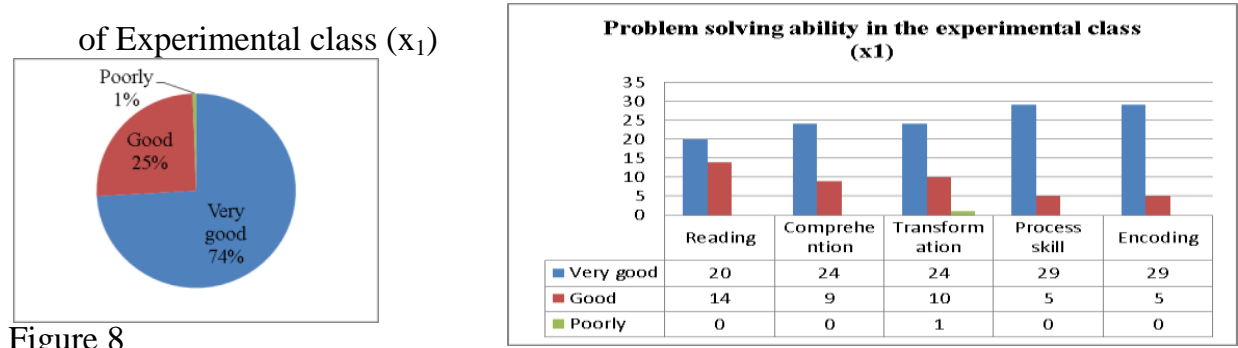

Figure 8

The distribution of student problem solving ability in the experimental class $\left(\mathrm{x}_{1}\right)$

Based on the results of post-test analysis between the three classes, it can be seen that the experimental class $\left(\mathrm{x}_{1}\right)$ is superior to the experimental class $\left(\mathrm{x}_{2}\right)$ and the experimental class $\left(\mathrm{x}_{2}\right)$ is superior to the control class $\left(\mathrm{x}_{3}\right)$. The result showed problem solving ability in control class was $35 \%$ had excellent problem solving ability, $38 \%$ were in good category, and $27 \%$ were in poor category. While for the experimental class $\left(\mathrm{x}_{2}\right) 54 \%$ had excellent category, $31 \%$ were in good category, and $15 \%$ were in poor category. For the experimental class $\left(\mathrm{x}_{1}\right), 74 \%$ had very good problem solving ability, $25 \%$ were in good category, and $1 \%$ were in poor category. The results of the three classes can be seen in Figure 6, Figure 7, and Figure 8.

$$
\begin{aligned}
& 6 \mathrm{~m} \\
& \text { Cost }=\left(L_{\text {garden }}-L_{\text {pool 1 }}-L_{\text {pod } 2}\right) \times \operatorname{cort} / \mathrm{m}^{*} \\
& =\left(L_{\square}-L_{O 1}-L_{O 2}\right) \times R P 50.000 \\
& =\left(P \times \ell-\pi r_{1}^{2}-\pi r_{3}^{2}\right) \times 50.000 \\
& =\left(8 \times 6-\frac{22}{7} \cdot \frac{2,1}{2} \cdot \frac{2.1}{2}-\frac{22}{7} \cdot \frac{2,8}{2} \cdot \frac{2,8}{2}\right) \times 50.000 \\
& =\left(48-\frac{6.93}{2}-6.16\right) \times 50.000 \\
& =(48-3,465-6,16) \times 50.000 \\
& =38,375 \mathrm{~m}^{2} \times 50.000 \\
& =19.7 .750 \\
& \text { So, the cost of planting grass is Rp } 1.918 .750 \text { - }
\end{aligned}
$$

Figure 9

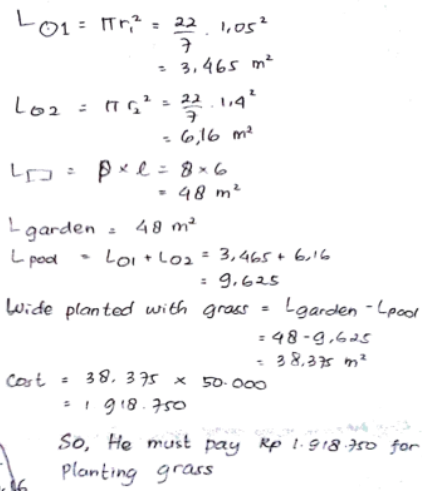

Two Sample of student's work on post-test with same question

From the student's work it can be seen that with the same problem, each student uses their own method to solve the problem. From the first student, he can finish first changing the story problem into the form of an image, then doing the transformation process and proceed with calculating and writing the final answer. While for the second student, he did the transformation process one by one without making a picture first. However the process he did was correct and he could find and write down the answers correctly. 
To find out students' perceptions of the implementation of jumping task based on CPS, an in-depth interview was conducted to the two students from the experimental class $\left(\mathrm{x}_{1}\right)$. The quotations from the interviews were presented below.

Researcher : After reading the question, do you immediately understand?

Student $\quad$ : I can understand the problem after reading the question twice.

Researcher : Do you have difficulty in solving problems?

Student : Initially yes ma'am, because I have to change the question to the shape of the picture, but after drawing, I can finish it

Researcher : Do you have difficulty doing calculations?

Student : No ma'am

Researcher : Can you solve all the questions smoothly?

Student : Yes ma'am

Researcher : Have you ever worked on a problem like this before?

Student : No ma'am, I usually do questions in the form of pictures

Researcher : What do you think about this learning?

Student $\quad:$ "... learning in class is fun, making us excited to learn, especially when doing the exercises. The problem is challenging to do ..."

Based on the interview results above, it can be seen that learning using jumping tasks based on CPS increases students' enthusiasm for learning. Students can ask with each other in a group. The interview results show a positive response from students, students enjoy learning so that they can improve their problem solving abilities. The results of the post-test also showed that students who learned using jumping tasks based on CPS only $1 \%$ entered the poor category.

\section{DISCUSSION}

The research is conduct to examine the effect of jumping task based on CPS on the students' problem-solving ability. The results shows that implementation of jumping task based on CPS indicates more effective compared with the implementation of sharing task based on CPS and conventional model. The result of this study is in line with the study conducted by Purwati (2015). This study shows that students' problem solving in mathematics that applied CPS is better than students' problem solving in mathematics that applied conventional model. The focus of CPS is on problem-solving skills and followed by strengthening skills. CPS provides the chance for students to improve problem-solving ability as the students were given an opportunity to develop their ideas and choose the most appropriate and effective ideas to solve problems (Rahman, 2015). In addition, students were not only trained to memorize concepts, but also encouraged to practice understanding and solving problem as well as to expand their thinking process skill. Students were given the chance to interact with each other to find and share various ideas obtained by students. The teachers as a facilitator must be able to be open so it can provide equal opportunities for all students to convey the ideas obtained. It also provides direction to students if students have difficulty in problemsolving process. 
During learning, students in the group consisted of students with high ability and low ability. They were given jumping tasks exercises that involved questions level above the demands of the current curriculum. This condition encourages the students to interact and help each other in one group to solve problem. Students with less ability would try to ask questions, while students who would solve the problems are able to help their friends in one group (Damayanti et al., 2017; Hobri, 2016; Hobri \& Susanto, 2016). The results of interviews with students in the experimental class $\left(\mathrm{x}_{1}\right)$, showed a positive response from students in learning using jumping tasks based on CPS. Students feel more enthusiastic and feel challenged in learning. There is a positive response from students and is supported by the results of an increase in the average post-test of students, as well as an increase of more than $50 \%$ of students entering the high category. It shows that jumping task based CPS effective to improve students' problem solving abilities.

Jumping task is an element of Lesson Study for Learning Community (LSLC), the other elements of LSLC are collaborative learning, caring community, and learning community. LSLC focuses on how students can learn from each other and gain experience working together in groups to improve quality in the learning process (Hobri \& Susanto, 2016, Marhamah et al., 2017; Saito, et al., 2015). The most important part of the LSLC is what is done and how students respond in groups, so that students feel comfortable and can interact in learning activities so that the ability of each student can develop (Hobri, 2016). By providing practice on jumping tasks and using the CPS learning model can be used as an effective way to improve problem-solving ability. Students were given difficult problem-solving exercises that can encourage them to interact. To find the solutions, teachers can apply CPS learning steps and support the learning process by collaborative learning, caring, and learning community. The result of this study was also in line with the study of Hobri (2016) that student who gets implementation of collaborative learning, caring community, and jumping task and use student worksheet based on scientific approach activity is very good, the student discussion, solve problem, and democratic situation is very good.

The results of this study indicated that students taught using sharing tasks based on CPS was better than those taught using conventional model. These findings indicated that students who were high in ability and had found a way of problem-solving were less able to interact with low-ability students and low-ability students were shy to ask a friend of higher ability (Asari, 2017). What is more, students who had found one way of problem solving tended not to try to find another solution to a problem. The lack of interaction and the inability to search for another solution caused the student ability hardly developed (Damayanti et al., 2017).

In the control class where applied conventional models dominated by lectures and written assignments, the findings showed that learning by conventional models had significantly less influence than did learning by jumping tasks based on CPS and sharing tasks based on CPS (Purwati, 2015; Rahman, 2015). In control class, students tend to be passive because they had to listen to the teacher's explanation. Teachers acted as the learning centre, so students were less actively involved to think (Purwati, 2015). 
Most of the students understood the explanation when listening to the teacher's explanation, but they were confused when given the exercises about solving problems primarily.

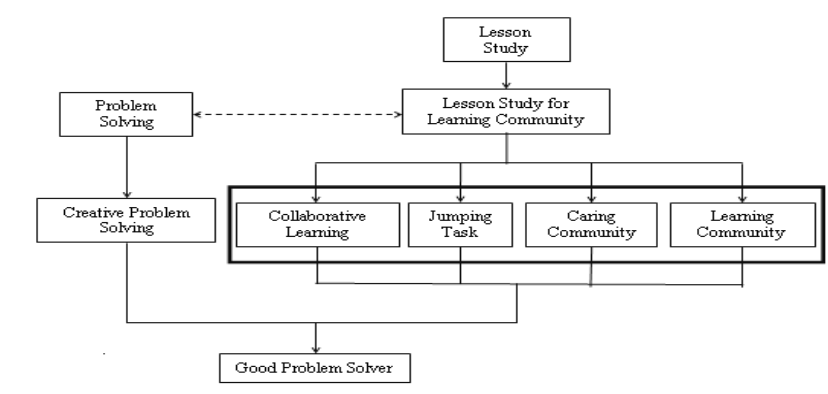

Figure 10

Flow of Achievement of Good Problem Solver through Jumping Task based on Creative Problem Solving (CPS)

Notes:

\section{- - : Indirect connected}

: Direct connected

LSLC is a part of LS that focuses on students' activity. LSLC is involved in 4 aspects, collaborative learning, jumping task, caring community, and learning community. The implementation of LSLC can increase students' problem solving abilities, combined with jumping tasks, sharing tasks, and problem solving tests. Learning is carried out with creative problem solving (CPS). It can be concluded that learning with the LS principle, LSLC, combined with CPS will make students a good problem solver. The process of achieving conclusion in Good Problem-solver through jumping task based on CPS is presented in Figure 10.

\section{CONCLUSION}

The research results proves that jumping tasks based on CPS is more effective for improving students' problem solving abilities compared with the implementation of sharing task based on CPS and conventional model. Students can learn by interacting and helping each other students in solving problems. The teachers as a facilitator must be able to be open so it can provide equal opportunities for all students to convey the ideas obtained. It also provides direction to students if students have difficulty in problem-solving process. Other result showed that application of sharing task based on CPS posed significant effects on students' problem-solving abilities compared to the application of conventional model and good problem solver could be built through combination between Lesson Study for Learning Community (LSLC) and CPS.

\section{ACKNOWLEDGMENT}

We gratefully acknowledge the support from Research and Community Service Institutions (LP2M) Jember University, and Faculty of Teacher Training and Education, especially Postgraduate Program of Mathematics Education. 


\section{REFERENCES}

Anwar, B. (2017). Pengaruh Collaborative Learning dengan Teknik Jumping Task terhadap Keterampilan Befikir Kritis dan Hasil Belajar IPA Siswa SMP [The Effect of Collaborative learning with Jumping Task toward Critical Thingking and Students' Achievement Topic Scieene in Junior High School]. Dissertation. Malang : State University of Malang. Diakses dari http://karya-ilmiah.um.ac.id/index.php/ disertasi/article/view/56580.

Asari, S. (2017). Sharing and Jumping Task in Collaborative Teaching and Learning Process. Didaktika: Jurnal Pemikiran Pendidikan, 23 (2), 184-188.

Basadur, M. (1998). The Basadur Simplex Creative Problem-Solving Profile Inventory: Development, Reliability and Validity. Management of Innovation and New Technology Research Center, 83, 1-77, December 1998.

Basadur, M., Graen, B. G., Green G. S. (1982). Training in Creative Problem Solving: Effects on Ideation and Problem Finding and Solving in an Industrial Research Organization. Organizational Behavior And Human Performance, 30 (1), 41-70.

Caprioara, D. (2015). Problem Solving-Purpose and Means of Learning Mathematics in School. Procedia-Social and Behavioral Sciences, 191, 1859-1864, 2 June 2015.

Clements, Ken, \& Ellerton, N. F. 1996. The Newman Procedure for Analysing Error on Written Mathematical Tasks. The University of New Castle: Faculty of Education.

Damayanti, N., Suarsana, I., \& Suryawan, I. (2017). Improvement of Literacy Ability of Student Mathematics through Application of Collaborative Learning Model. Jurnal Matematika, Sains, dan Pembelajarannya, 11(1), 33-42.

Fatimah, I., Hendayana, S., \& Supriatna, A. (2018). Didactical design based on sharing and jumping tasks for senior high school chemistry learning. Journal of Physics: Conference Series 1013012094.

Fauziah, E. W., Hobri, Yuliati, N., \& Indrawanti, D. (2019). Student's creative thingking skills in mathematical problem posing based on lesson study for learning community (LSLC). IOP Conference Series: Earth and Environmental Science $\mathbf{2 4 3}$ (2019) 012142.

Hobri, \& Susanto. (2016). Collaborative Learning, Caring Community, and Jumping Task Based on Scientific Approach Student Worksheet: An Alternative of Mathematics Learning in the Era of the MEA. Proceedings of National Seminar of Mathematics and Learning, Jember, October 2016, 7-17.

Hobri, Dafik, \& Hossain, A. (2018). The Implementation of Learning Together in Improving Students' Mathematical Performance. International Journal of Instruction, 11(2), 483-496.

Hobri, Nazareth, E., Romlah, S., Safitri, J., Yuliati, N., Sarimanah, E., Monalisa, L A., \& Harisantoso, J. (2019). The students' creative thinking ability in accomplishing 
collaborative learning-based open-ended questions. IOP Conference Series: Earth and Environmental Science 243 (2019) 012145.

Hobri. Romlah, S., Prihandoko, A. C., Safitri, J., \& Nazareth, E. (2018). Students' metacognitive ability in mathematical problem solving learning based on lesson study for learning community (LSLC). Journal of Physics : Conference Series. 1088 (2018) 012064.

Hobri. Safitri, J., Romlah, S., Prihandoko, A. C., Safitri, J., \& Nazareth, E, (2018). Students' collaborative ability in learning geometry transformation using scientific approach based on learning community. Journal of Physics : Conference Series. 1088 (2018) 012027.

Hobri, Septiawati, I., Prihandoko, A.C. (2018). High-order thinking skill in contextual teaching and learning of mathematics based on lesson study for learning community. International Journal of Engeneering and Technology. 7 (3) (2018) 1576-1580.

Hobri. (2009). Model-Model Pembelajaran [Learning Innovative Models]. Jember: Center for Society Studies.

Hobri. (2016). Lesson Study for Learning Community: Review of Short Term on Lesson Study V in Japan. Proceedings of National Seminar of Mathematics Education, Madura, 28 May 2016, p.12-21.

Indrawanti, D., Hobri, Hadi, A. F., Fauziah, E. W. 2019. Critical thinking ability in solving triangle problems based on lesson study for learning community (LSLC). IOP Conference Series: Earth and Environmental Science 243 (2019) 012146.

Isaksen, S., Puccio G. J., \& Treffinger D. J. (1993). An Ecological Approach to Creativity Research: Profiling For Creative Problem Solving. Journal of Creative Behavior, 27(3), 149-170.

Jayanti, E., Supriatna, A., Komalia, K. (2016). Sharing and Jumping Task Based Lesson Design of Conservation of Mass Concept, Proceeding International Conference on Lesson Study (ICLS) 7th 3-5 November 2016. pp. 62-66 Malang : University of Muhammadiyah Malang Indonesia. https://www.academia.edu/36635826/Sharing_and Jumping_Task_Based_Lesson Design_of_Conservation_of_Mass_Concept

Kandemir, M. (2009). The Use of Creative Problem Solving Scenarios in Mathematics Education: Views of Some Prospective Teachers. Procedia - Social and Behavioral Sciences, 1(1), 1628-1635.

Marhamah, Mustafa, \& Melvina. (2017). The Influence of Collaborative Learning Model Based on the Lesson Study Learning Community (LSLC). Jurnal Ilmiah Mahasiswa Pendidikan Fisika (JIMPF), 2(3), 277-282.

Nofrion. (2019). Peningkatan Aktivitas Belajar Siswa melalui Penerapan Metode "Jumping Task" pada Pembelajaran Geografi [The improving of learning activity through jumping task in Geografi learning]. Jurnal Geografi. 9 (1), pp. 11-20, 
http://jurnal.unimed.ac.id/2012/index.php/geo

Phaksunchai, M., Kaemkate, W., \& Wongwanich, S. (2014). Research and Development of a Training Package for Developing Creative Problem Solving of Undergraduate Students. Procedia-Social and Behavioral Sciences, 116(21 Februari 2014), 4824-4828.

Puccio, G., Firestien, R., Coyle, C., \& Masucci, C. (2006). A Review of the Effectiveness of CPS Training: A Focus on Workplace Issues. Creativity and Innovation Management, 15(1), 19-33.

Purwati. (2015). Effectiveness of Creative Problem Solving to The Ability of Mathematics Problem Solving in High School Students. Jurnal Ilmiah Edukasi Matematika (JIEM), 1(1), 39-55.

Putri, R. I. I., \& Zulkardi, Z, 2019, Designing Jumping Task on Percent using PMRI and Collaboartive Learning, International Journal on Emerging Mathematics Education (IJEME). 3 (1). pp. 105-116 March 2019. http://journal.uad.ac.id/index.php/ IJEME/article/view/12208.

Rahman, A. (2015). The Influence of Creative Problem Solving (CPS) Model in The Mathematics Learning of The Ability of Creative Thinking in Junior High School Students. Edu-Mat Jurnal Pendidikan Matematika, 3(1), 67-74.

Saadah, L. Z. K., Hobri, Irvan, M. (2019). The application of problem based learning (PBL) based on lesson study for learning community (LSLC) to improve students' creative thinking skill. IOP Conference Series: Earth and Environmental Science $\mathbf{2 4 3}$ (2019) 012141.

Saito, E., Murase, M., \& Tsukui, A. (2015). Lesson Study for Learning Community. New York: Routledge.

Saito, E., Watanabe, M., Gillies, R., Someya, I., Nagasima, T, Sato, M., \& Murase, M. (2015). School Reform for Positive Behaviour Support Through Collaborative Learning: Utilising Lesson Study for a Learning Community. Cambridge Journal of Education, 45(4), 489-518.

Sato, M. (2012). Reform Learning with Learning Community and School Development Creation Model $21^{\text {st }}$ Century. International Lesson Study Conference, Hotel Sultan, 3 September 2012.

Scherer, R., \& Gustafsson, J. (2015). The Relations among Openness, Perseverance, and Performance in Creative Problem Solving: A Substantive-Methodological Approach. Thinking Skills and Creativity, 18, p.4-17, December 2015.

Sudiarta, I. (2005). Developing the Competence of Divergent and Critical Thinking Through the Solution of Mathematics' Problem Solving based on open ended. Jurnal Pendidikan dan Pengajaran IKIP Negeri Singaraja, p.527-548, October 2005.

Sugiyono. (2017). Mixed Methods (Research Methods Combination (Mixed Methods)). Bandung: Alfabeta. 